\title{
高温面に衝突する微小液滴挙動と液温の関係
}

\section{Effect of Liquid Temperature on Behavior of Droplet Impinging onto a Hot Surface}

\section{○学 井上 慎也 ${ }^{1}$, 学 堀 智朗 ${ }^{1}$, 正 喜多 由拓 ${ }^{1,2}$, 正 日高 澄具 ${ }^{2}$} 福田 啓之 ${ }^{3}$, 正 河野 正道 ${ }^{1,2}$, ○正 高田 保之 ${ }^{1,2}$

Shinya Inoue ${ }^{1}$, Tomoro Hori ${ }^{1}$, Yutaku Kita ${ }^{1,2}$, Sumitomo Hidaka $^{2}$

Hiroyuki Fukuda ${ }^{3}$, Kohno Masamichi ${ }^{1,2}$, Yasuyuki Takata ${ }^{1,2}$

${ }^{1}$ Kyushu University, 744 Motooka, Nishi-ku, Fukuoka 819-0395, Japan

${ }^{2}$ International Institute for Carbon-Neutral Energy Research (WPI-I²NER), Kyushu Univ.

${ }^{3}$ JFE Steel Corporation, 2-3 Uchisaiwai-cho 2-chome, Chiyoda-ku, Tokyo 100-0011, Japan

Key Words: Oxide layer, Quenching, Film boiling, Spray cooling, Droplet impingingment

\section{1. 緒言}

製鉄工程の泠却においてスプレー冷却は最も使用されている冷却技術であり，その中の急冷開始温度 (又はクエンチ 温度)はスプレー冷却の重要な特性の一つである. 福田らは酸化スケールの種類と厚さがスプレー冷却特性に及ぼす影 響を調べ, 酸化スケール種類によって膜沸騰域(急冷開始前)からの冷却速度が異なること, および酸化スケール厚みが 増すとみかけのクエンチ温度が上昇することを報告した(1).これを踏まえて, 著者らは酸化スケールの影響を含めたクエ ンチ開始のメカニズムを明らかにすることを目的とし, 酸化スケールを有する高温面を用いて単一液滴衝突実験を行って きた. 最近, 固液接触時の非定常熱伝導を考えることで, 上記の結果を説明できることが分かってきた ${ }^{(2)}$.つまり, クエン チ開始は酸化スケールの種類や厚さに関わらず, 固液が接触する瞬間の界面温度で決まる可能性がある. 本報ではこ のモデルの一般性を確かめるべく, 液滴温度を変化させて実験を行い, 液滴挙動と固液界面温度の関係を調査する.

\section{2. 実験装置及び方法}

試料をヒーターに挿入し, 目標の壁面温度 $T_{\mathrm{w}}$ まで加熱する. 定常状態で $T_{\mathrm{w}}$ に達したところで液滴を滴下し, ハイスピ ードカメラを用いて液滴の衝突様相を観察する. 本実験での液滴径は $600 \pm 30 \mu \mathrm{m}$, 液滴速度は $1.48 \pm 0.1 \mathrm{~m} / \mathrm{s}$ であり, 液滴温度は $10{ }^{\circ} \mathrm{C}, 30{ }^{\circ} \mathrm{C}, 50{ }^{\circ} \mathrm{C}$ である. 試料に付与した酸化皮膜は 5 種類 $\left(\mathrm{TiO}_{2}, \mathrm{Cr}_{2} \mathrm{O}_{3}, \mathrm{Al}_{2} \mathrm{O}_{3}, \mathrm{SiO}_{2}-\mathrm{ZrO}_{2}, \mathrm{Fe}_{3} \mathrm{O}_{4}\right)$ で あり皮膜厚さは約 $100 \mu \mathrm{m}$ とした。 また, 実験は試料表面の酸化を防ぐために窒素雾囲気にて行う.

\section{3. 実験結果及び考察}

全ての条件において, 高温度域に推移するにつれて固液接触時間, 最大液滴 拡がり径 $D_{\max }$ と初期液滴径 $D_{\mathrm{d}}$ の比 $\left(D_{\max } / D_{\mathrm{d}}\right)$ がともに小さくなり, ある温度以上で ほぼ一定となった.この液滴挙動が遷移する点がクエンチ点に相当すると考えら れる(2), (3). 一方で, 液滴温度を高くすると, 各スケールにおいて液滴挙動の遷移 温度 $T_{\mathrm{w}}$ が低温域にシフトすることが分かった. 接触界面温度 $T_{\mathrm{S}}$ で整理すると, い ずれの液滴温度においても, 固液接触時間および $D_{\max } / D_{\mathrm{d}}$ の遷移温度は約 $250{ }^{\circ} \mathrm{C}$ で一致した. 図 1 では代表して $T_{\mathrm{S}}$ と $D_{\max } / D_{\mathrm{d}}$ の関係について $\mathrm{Fe}_{3} \mathrm{O}_{4}$ と No

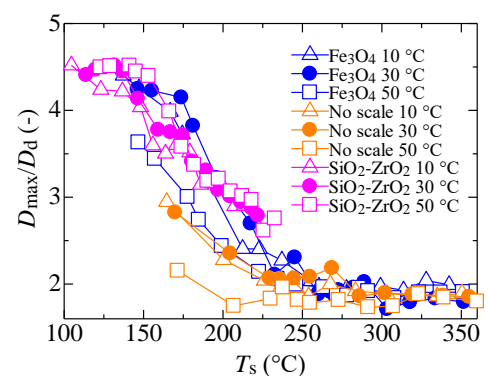

Fig. $1 T_{\mathrm{S}}$ vs $D_{\max } / D_{\mathrm{d}}$. scale と $\mathrm{SiO}_{2}-\mathrm{ZrO}_{2}$ の三つのサンプルについてまとめた. 以上の結果は酸化皮膜の種類および厚さの影響を検討した先 行研究(2)の結果と同じであり, クエンチ開始の界面温度は一定の值をとる可能性が示された.

\section{4. 結言}

本研究では冷却水温度が冷却に与える影響を調查した. 本実験から界面温度で定義したクエンチ温度は冷却水温度 によらず約 $250^{\circ} \mathrm{C}$ 付近であることが確認できた. 以上よりスプレー冷却中の見かけのクエンチ温度は液温の影響を受け， 冷却水温度が下がるほど急冷開始が早くなることが示された。

\section{参考文献}

(1) 福田·他 6 名, 鉄と鋼, 100-12 (2014), 1514.

(2) Tsukamoto et al., Applied Thermal Engineering, 179 (2020), 115682.

(3) Negeed et al., Int. J. Therm. Sci., 70 (2013), 65. 